\title{
The Antibacterial Activity of Lactic Acid Bacteria from Pickled Spondias dulcis (Ambarella) against Foodborne Pathogens
}

\author{
Nur Ilida Mohamad ${ }^{1,2}$, Musaalbakri Abdul Manan² and Norrakiah Abdullah Sani ${ }^{1, *}$ \\ ${ }^{I}$ Department of Food Sciences, Faculty of Science and Technology, Universiti Kebangsaan Malaysia, \\ 43600 Bangi, Selangor, Malaysia \\ ${ }^{2}$ Food Science and Technology Research Centre, Malaysian Agricultural Research and Development \\ Institute, 43400 Serdang, Selangor, Malaysia
}

('Corresponding author's e-mail: norrasani@ukm.edu.my, norrasani@yahoo.co.uk)

Received: 27 October 2020, Revised: 31 May 2021, Accepted: 27 June 2021

\begin{abstract}
Pickled fruits are popular condiment not only in Malaysia but in many other countries as well. During the natural pickling process, the lactic acid bacteria are known to be able to produce several antibacterial compounds. The pickled Spondias dulcis or ambarella is among commonly consumed pickled fruit in Malaysia and may be a promising source of lactic acid bacteria. Application of lactic acid bacteria as an alternative to chemical food preservative is believed as natural, safer and sustainable. This study was carried out to isolate and identify lactic acid bacteria from Malaysian local pickled Spondias dulcis and to determine their antibacterial activity against selected Gram-positive and Gram-negative foodborne pathogens. The isolation of lactic acid bacteria was done using a standard method and the isolated colonies with positive preliminary identification based on their morphology on agar, Grampositive staining characteristic and their negative catalase reaction were chosen for identification with polymerase chain reaction amplification of $16 \mathrm{~S}$ rRNA gene and sequencing. A total of 2 lactic acid bacteria have been successfully isolated and identified as Lactobacillus fermentum (LABS1) and Enterococcus durans (LABS2). Both isolates were able to demonstrate antibacterial activity against foodborne bacterial pathogens used in this study. This result suggested that the isolated lactic acid bacteria from pickled $S$. dulcis may have a potential to be applied as natural preservative to control the growth and fight against certain pathogens in food.
\end{abstract}

Keywords: Spondias dulcis, Antibacterial agent, Lactic acid bacteria, Foodborne pathogens, Food preservatives

\section{Introduction}

The food supply chain is very complex and consisting of big, small and medium sized industries involve in providing raw materials, food processing, packaging, distribution and retailing before reaching the consumer for consumption [1]. Many approaches have been applied in each sector of food supply chain to improve food hygiene and food safety aspects. This including reduction or elimination of microbiological hazard that could resulted in food poisoning due to occurrence of pathogenic bacterial strains at certain level. Food poisoning is a significant food safety issue that have a direct impact to public health [1].

Currently, the issue of resistant pathogenic species that caused foodborne illness have emerged due to microbial ability to adapt and change according to changes in their environments [2]. These environmental changes have started during agriculture farming and field practices while growing crops and raising the livestock as raw materials to the changes in food production, preservation and packaging [2]. These changes have altered the microorganisms and created the emergence of new pathogenic strains that previously may not have caused harm to the food industry [2]. In current farm and field, an excessive used or misused of antimicrobial agents to prevent or to treat diseases in animals and plants caused by microorganisms have created a resistant species. Later, the resistance genes may also be entering the food system through cross-contamination during processing or storage [1]. Due to the existence of resistant species, the food industry is having more difficulties in fighting foodborne pathogens and needs to find ways to eliminate and inhibit these pathogens. At the same time, consumers prefer foods that are not only 
tasty but also safe and have fewer chemical additives [3]. Therefore, the application of natural preservatives may have a huge potential as it may fulfil the food safety aspect and at the same time will meet the consumer trend [4].

The lactic acid bacteria (LAB) are a group of bacteria known to be able to produce several antibacterial compounds such as organic acids, bacteriocins and hydrogen peroxide. This ability has made them a good source as natural preservatives. The LAB also has a Generally Recognized as Safe (GRAS) status granted by the United States Food and Drug Administration (USFDA) that indicates it as safe to consume by human [5]. This recognition also has strengthened the potential of LAB application as an alternative preservative to the commonly used synthetic chemical preservatives. Natural food preservatives are those that derived from plant, animals or microbial origin and this included the LAB and their metabolites. The synthetically derived chemical preservatives are known to cause harm to human health if taken excessively for certain period of time [4].

The LAB also is an important group of industrial microorganisms that has a long usage in food fermentation as natural colonizers or are intentionally added as starter cultures. Other than dairy products, plant-based fermented products such as pickled fruits and vegetables can also be a good source of LAB [6]. In Malaysia, local fermented products such as pickles of various fruits and vegetables have long been in the market. S. dulcis or known as kedondong in Malay language or ambarella is an underutilized fruit that belongs to the Arecaceae family [7]. It can be eaten fresh or processed into pickles. The pickled $S$. dulcis is commonly consumed in Malaysia together with other types of pickled fruits such as pickled mango (Mangifera indica), guava (Psidium guajava) and papaya (Carica papaya). In recent years, researchers have reported on the LAB species with antibacterial property isolated from pickled vegetables including pickled radish, carrot, bitter bean, garlic and cabbage [8], and pickled fruits including jackfruit, plum, lemon, olive, apple and dates [9]. On the other hand, according to Mohammed et al. [7], the $S$. dulcis fruit extract at different fruit maturity stages have shown antibacterial effect against several food pathogens. However, there are no reports on the LAB isolated from pickled $S$. dulcis and their antibacterial property against foodborne pathogens. In view of these findings, this study was carried out to isolate and characterize LAB from local pickled $S$. dulcis that is commonly consumed in Malaysia and also to identify whether the isolated LAB have the antibacterial property to inhibit commonly known Gram-positive and Gram-negative foodborne pathogens, to be potentially used as natural preservative in the future.

\section{Materials and methods}

\section{Sample collection}

The pickled $S$. dulcis samples were collected randomly from a variety of sources including stalls, wet markets and supermarkets located in Hulu Langat area of Selangor, Malaysia. Samples were kept chilled in ice box with ice replacer during transportation and taken to the laboratory for analysis.

\section{Isolation of lactic acid bacteria (LAB) from local pickled $S$. dulcis samples}

A $10 \mathrm{~g}$ of sample was obtained following the standard methodology for preparation of sample homogenate for microbiological analysis and weighed using aseptic technique [10]. The sample then was homogenized in a stomacher (Seward Medical, UK) for $30 \mathrm{~s}$ in $90 \mathrm{~mL}$ of Ringers solution (Oxoid, UK). Figure 1 showed the $S$. dulcis sample on sterile Petri dish before weighing process.

An amount of $1 \mathrm{~mL}$ of the diluent from prepared homogenate as described above was pipetted into 9 $\mathrm{mL}$ sterile Ringers solution for serial decimal dilution. The number of dilutions prepared depended on microbial density of each sample, but at least 3 consecutive dilutions that could provide single colony growth were chosen. Then, $1 \mathrm{~mL}$ aliquots of each dilution were transferred to a Petri dish using the pour plate method. The sterile molten de Man, Rogosa and Sharpe agar (MRS, Difco, USA) of approximately $15 \mathrm{~mL}$ was poured into plates to form a layer, swirled and let to solidify. The MRS agar is a recommended medium for the cultivation of Lactobacillus and other lactic acid bacteria species and was prepared earlier following the manufacturer's instruction and was cooled to $45 \pm 2{ }^{\circ} \mathrm{C}$ before use. The solidified plates were inverted and placed in an anaerobic jar containing an anaerobic gas generator sachet (AnaeroGen, Oxoid, UK) to create an anaerobic environment suitable for the LAB growth before incubation at $37 \pm 2{ }^{\circ} \mathrm{C}$ for 24 to $48 \mathrm{~h}$ in an incubator.

After incubation period, each plate was examined and plate containing single colonies that were white or cream in color and round shape were counted and recorded as the presumptive number of LAB and later expressed as colony forming unit/gram of sample (CFU/g). The selected isolates then were subcultured onto fresh MRS agar following the method done by Kam et al. [11]. The sub-culturing process 
was continued at least 3 times and the isolates that were able to maintain their characteristics during each sub-culturing were proceeded for Gram staining and catalase reaction test. The isolates grew in MRS broth (Difco, USA) and supplemented with $20 \%$ glycerol (Sigma, USA), were stored at $-20 \pm 2{ }^{\circ} \mathrm{C}$ until being used for identification study.

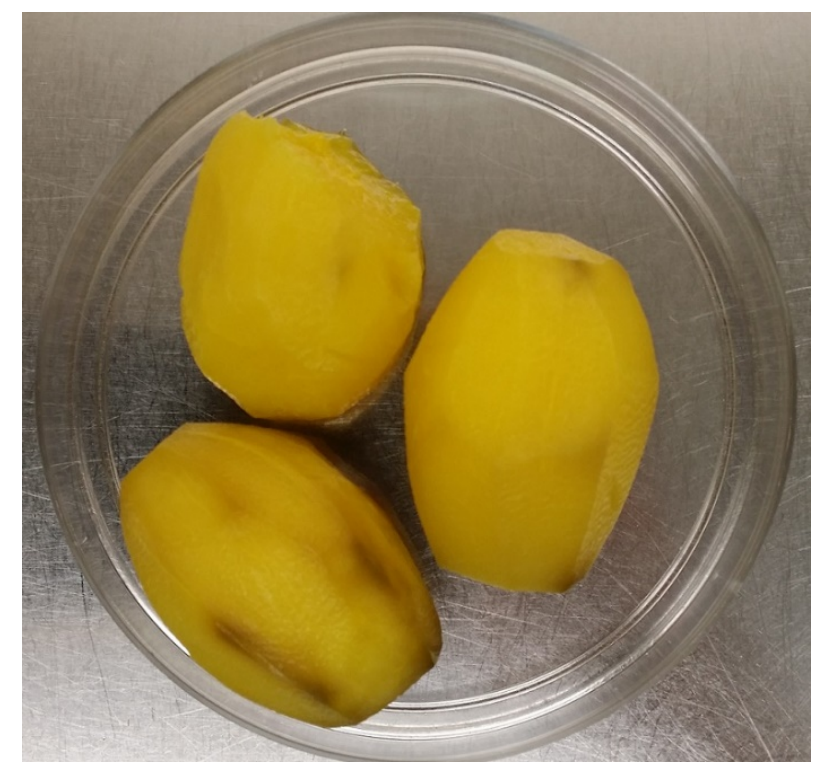

Figure 1 Pickled Spondias dulcis (ambarella or kedondong) on sterile Petri dish before weighing for isolation of lactic acid bacteria (LAB).

\section{Morphological and biochemical identification of LAB isolates}

The isolates that were viable following sub-culture and met the characteristics of LAB on MRS agar (white color, round shape) (Figures 2 and 3) were subjected to morphological and biochemical identification involving Gram staining and catalase reaction tests. The Gram staining was conducted using a single colony of each LAB isolate, following the standard protocol for Gram staining while catalase reaction was performed on sterile microscope glass slide using $3 \%$ hydrogen peroxide (Sigma, USA) according to Nanasombat et al. [12] and Nurul Huda and Norrakiah [13]. The Gram staining result was recorded as whether the isolates were of Gram-positive or Gram-negative bacteria while the catalase reaction was recorded as either positive or negative of catalase activity.

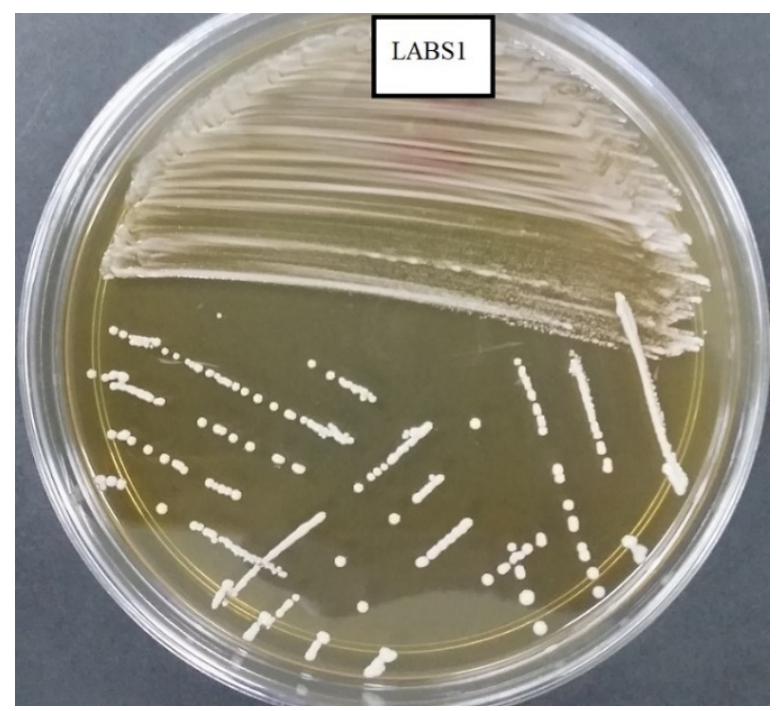

Figure 2 Morphology of Lactobacillus fermentum (LABS1) on MRS agar. 


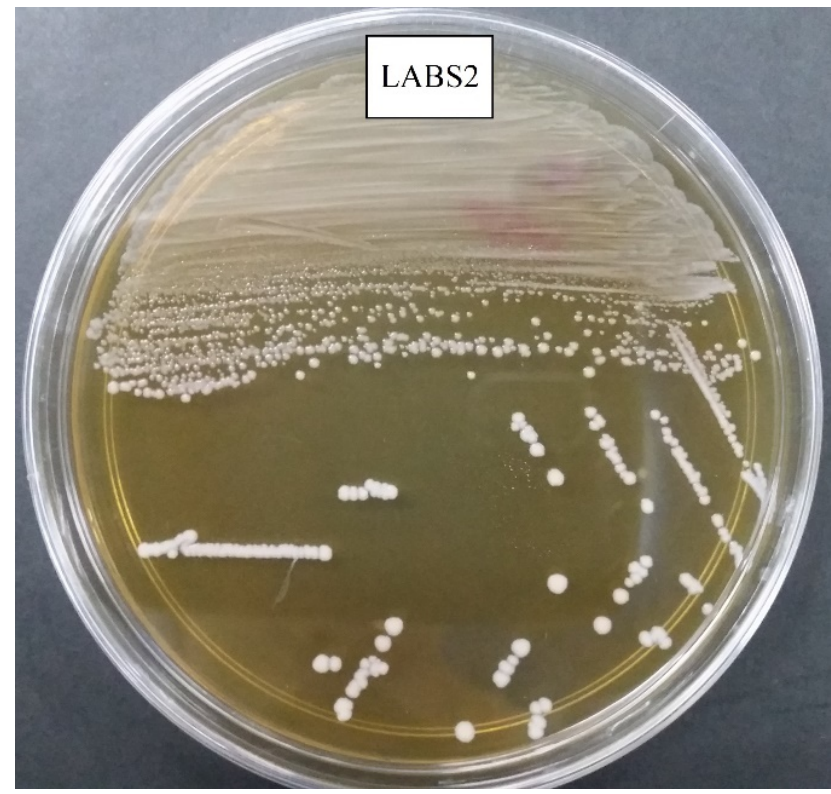

Figure 3 Morphology of Enterococcus durans (LABS2) on MRS agar. LAB

Molecular identification of LAB isolates by amplification and sequencing of 16S rRNA gene of

The isolates with Gram-positive and catalase negative reaction were further identified at molecular level by using method of amplification and sequencing of 16S rRNA gene. The genomic DNA of the LAB isolates was extracted using QIAamp ${ }^{\circledR}$ DNA Mini Kit (QIAGEN, USA). The 16S rDNA gene was amplified by polymerase chain reaction (PCR, ) using primers 27-f : 5' - AGT TTG ATC CTG GCT CAG -3' and 1492-r : 5' - GTT TAC CTT GTT ACG ACT T-3' as mentioned by Tan et al. [14] and Nur ilida et al. [15]. The PCR was carried out in a thermal cycler in a total volume of $50 \mu \mathrm{L}$ containing $25 \mu \mathrm{L}$ Taq Mix Red, $2 \mu \mathrm{L}$ of each primer, $1 \mu \mathrm{L}$ extracted DNA and PCR grade $\mathrm{H}_{2} \mathrm{O}$ to reach final volume. The conditions for the PCR were set as follows: 1 cycle of $95^{\circ} \mathrm{C}$ for $15 \mathrm{~s} ; 40$ cycles of $95{ }^{\circ} \mathrm{C}$ for $15 \mathrm{~s}, 55^{\circ} \mathrm{C}$ for $15 \mathrm{~s}$ and $72{ }^{\circ} \mathrm{C}$ for $30 \mathrm{~s}$; and 1 cycle of $72{ }^{\circ} \mathrm{C}$ for $10 \mathrm{~min}$. The PCR products obtained were then separated on $1 \%(\mathrm{w} / \mathrm{v})$ agarose gel (GeneDirex, Taiwan) containing GelRed (Biotium, USA) using electrophoresis with constant voltage of $80 \mathrm{~V}$ for $55 \mathrm{~min}$ in $1 \mathrm{x}$ TBE buffer (UltraPure, USA). The sizes of DNA fragments were estimated using 1000 base pair (bp) DNA ladder. Sequencing of the PCR products were done at First Base Laboratories Sdn. Bhd., Malaysia. Nucleotide sequences were later analyzed using the BLAST program available online at https://blast.ncbi.nlm.nih.gov/Blast.cgi.

\section{Preparation of LAB isolates and its culture conditions for antibacterial activity study}

All the identified strains were maintained at $-20 \pm 2{ }^{\circ} \mathrm{C}$ in MRS broth supplemented with $20 \%$ glycerol (Sigma, USA) as a stock following the method done by Arena et al. [16]. The preparation of the LAB for antibacterial activity study was also done following the method reported by Arena et al. [16] where, $0.1 \mathrm{~mL}$ of the LAB glycerol stock were inoculated in $5 \mathrm{~mL}$ MRS broth, tightly screwed cap and incubated at $37 \pm 2{ }^{\circ} \mathrm{C}$ for $24 \mathrm{~h}$. Later, another $1 \mathrm{~mL}$ was taken from the overnight culture and transferred into $10 \mathrm{~mL}$ MRS broth and incubated for 18 - $24 \mathrm{~h}$ prior to antibacterial study.

\section{Preparation of pathogenic strains for antibacterial activity evaluation}

The method for preparation of the pathogenic strains for antibacterial activity evaluation was done according to Vahedi et al. [17]. A total of 5 Gram-positive and 5 Gram-negative bacterial strains that are significant to food safety issue were chosen as follows: 1) Gram-positive: Bacillus cereus ATCC $^{\circledR}$ $10876^{\mathrm{TM}}$, Enterococcus faecalis ATCC $^{\circledR} 19433^{\mathrm{TM}}$, Listeria innocua ATCC $^{\circledR} 33090^{\mathrm{TM}}$, Listeria monocytogenes $\mathrm{ATCC}^{\circledR} 7644^{\mathrm{TM}}$ and Staphylococcus aureus $\mathrm{ATCC}^{\circledR} 25923^{\mathrm{TM}}$ and 2) Gram-negative: Cronobacter muytjensii ATCC ${ }^{\circledR} 51329^{\mathrm{TM}}$, Escherichia coli $\mathrm{ATCC}^{\circledR} 48888^{\mathrm{TM}}$, Salmonella enterica serovar Poona NCTC 4840, Salmonella enterica serovar Typhimurium ATCC ${ }^{\circledR} 14028^{\mathrm{TM}}$ and Vibrio parahaemolyticus NCTC 10885. 
The strains were previously stored in glycerol at $-20 \pm 2{ }^{\circ} \mathrm{C}$ and were revived prior to use by transferring $20 \mu \mathrm{L}$ of the glycerol stock into $5 \mathrm{~mL}$ Tryptic soy broth (TSB, Oxoid, UK) and incubated at $37 \pm 2{ }^{\circ} \mathrm{C}$ for $24 \mathrm{~h}$. Later, $1 \mathrm{~mL}$ of these cultures were transferred into $10 \mathrm{~mL}$ TSB broth and again incubated at $37 \pm 2{ }^{\circ} \mathrm{C}$ for $24 \mathrm{~h}$. The bacterial suspension was then prepared to a turbidity of 0.5 McFarland standard $\left(\sim 1 \times 10^{8}\right.$ colony forming units CFU mL $\left.\mathrm{mL}^{-1}\right)$ by adding the sterile distilled water into the suspension until the desired turbidity was achieved. The turbidity was determined by placing the suspension bottle into a McFarland nephelometer (Becton Dickinson, USA) to get the correct reading.

\section{Antibacterial activity evaluation of LAB cell culture using agar spot test method}

The antibacterial activity of the LAB cell was tested using an agar spot test method by referring to Ozcelik et al. [18]. A volume of $5 \mu \mathrm{L}$ of the overnight culture of all LAB isolates were inoculated as a spot in the middle of MRS agar plate and incubated at $37 \pm 2{ }^{\circ} \mathrm{C}$ for $24 \mathrm{~h}$ anaerobically. Subsequently, a colony that grew in the middle of the plate, was overlaid with pathogenic strains $\left(\sim 1 \times 10^{8} \mathrm{CFU} \mathrm{mL}^{-1}\right.$, prepared as mention in the above section) that has been first mixed with $4 \mathrm{~mL}$ of soft Tryptic soy agar (TSA, Oxoid, UK). The overlaid plates were then incubated at $37 \pm 2{ }^{\circ} \mathrm{C}$ for $24 \mathrm{~h}$, aerobically. Zone of inhibition around the spots (diameter) were measured in $\mathrm{mm}$ and scored accordingly as done by Ozcelik et al. [18]. The LAB strains that were able to inhibit any of the pathogenic strains which was observed as a clear zone, indicated the antibacterial potential of the LAB strains and were further analyzed using LAB cell free supernatant by agar well diffusion method.

\section{method \\ Antibacterial activity evaluation of LAB cell free supernatant (CFS) using agar well diffusion}

Other than agar spot test method, the antibacterial activity of the LAB cell free supernatant (CFS) was also conducted using similar method by Sumathi and Reetha [19] and Yang et al. [20]. A $10 \mathrm{~mL}$ of overnight cultures of each LAB was centrifuged at $10,000 \mathrm{rpm}$ for $10 \mathrm{~min}$ at $4{ }^{\circ} \mathrm{C}$. The pellet was discarded and the CFS was filter-sterilized through a sterile $0.45 \mu \mathrm{m}$-pore-size filter (Sartorius Stedim, France). The $\mathrm{pH}$ of CFS for each of the $\mathrm{LAB}$ was determined using a $\mathrm{pH}$ meter (Eutech, Singapore). The CFS was then divided into 4 portions and used for antibacterial activity determination of the LAB isolates using well diffusion method. The first portion was the original CFS identified as untreated CFS (pH 4.07 to 4.45) and used as a control for this study where another portions of the CFS was treated as follows (i) CFS was adjusted from their initial $\mathrm{pH}(\mathrm{pH} 4.07$ to 4.45$)$ to $\mathrm{pH} 6.00 \pm 0.20$ using sterilized $1 \mathrm{~N} \mathrm{NaOH}$ and filtered through sterile $0.45 \mu \mathrm{m}$-pore-size filter (Sartorius Stedim, France). This experiment was to rule out antibacterial inhibition resulting from the production of organic acids and identified as neutralized CFS; (ii) CFS was treated with $1 \mathrm{mg} \mathrm{mL}^{-1}$ of catalase (Sigma-Aldrich, USA) at $25 \pm 2{ }^{\circ} \mathrm{C}$ for $30 \mathrm{~min}$ and (iii) $1 \mathrm{mg} \mathrm{mL}^{-1}$ of proteolytic enzyme, trypsin (Sigma-Aldrich, USA) at $37 \pm 2{ }^{\circ} \mathrm{C}$ for $2 \mathrm{~h}$. This part (ii) and (iii) was conducted to evaluate the possibility of antimicrobial inhibitory by the LAB isolates was due to hydrogen peroxide and bacteriocin, respectively.

Prior to applying the untreated CFS, neutralized CFS and both catalase and trypsin treated CFS for antibacterial activity using well diffusion method, the Luria Bertani (LB, Oxoid, UK) agar plates surface were inoculated by spreading $1 \mathrm{~mL}$ of the pathogenic bacterial culture $\left(\sim 1 \times 10^{8} \mathrm{CFU} \mathrm{mL}^{-1}\right.$, prepared as stated in the above section) over the entire agar surface using sterile cotton swab. A hole with a diameter of 5 to $6 \mathrm{~mm}$ were punched aseptically on each of the plate using the top edge of sterile tips. Then, a volume of $20 \mu \mathrm{L}$ of the same agar was added to the well in order to seal the base and avoid leakage of the sample added to the well. An amount of $70 \mu \mathrm{L}$ of the untreated CFS, neutralized CFS and enzymes treated CFS (catalase and trypsin) was introduced into each well respectively and left to dry before the agar plates were placed in an anaerobic jar with AnaeroGen and incubated at $37 \pm 2{ }^{\circ} \mathrm{C}$ for $48 \mathrm{~h}$ in an incubator. The inhibition zones (diameter) around the well filled with each type of CFS were measured in $\mathrm{mm}$ and recorded accordingly.

\section{Statistical analysis}

Data were analyzed using SAS 9.3 statistical software. A one-way analysis of variance was performed to evaluate significant differences between sample means. The level of significance was set at $\alpha=0.05$. All experimental results were expressed as mean values obtained from 3 replicates $(n=3)$ unless stated otherwise. 


\section{Results and discussion}

Isolation, morphological and biochemical identification

A total number of 11 pickled $S$. dulcis samples had been collected for LAB isolation analysis as mention in Table 1. All samples were acidic and initially were packed in a pickling medium by the sellers and one of the samples after taken out from the pickling medium and prior to weighing is shown in Figure 1. The viable LAB count found in the samples ranged from below detection limit $(<1.0 \times 10)$ to $1.0 \times 10^{4} \mathrm{CFU} / \mathrm{g}$ as shown in Table 1. Some pickled fruit and vegetable samples from Kalkota area with a very low amount of viable LAB were also detected [9]. Intentional chemical acidification during pickling process by addition of commercial acids such as apple cider vinegar was suggested as the main responsible factor as fermented products were expected to have a high count of LAB [9]. The acidification of the pickles was not happening due to fermentation thus prevent the LAB growth in the products. Other than that, the pickles may also have been prepared with a very high sugar, salt and commercial acids content where their $\mathrm{pH}$ values were also acidic but a low number of LAB might be able to withstand the conditions [8].

Table 1 Lactic acid bacteria (LAB) isolates from local pickled Spondias dulcis (ambarella or kedondong).

\begin{tabular}{|c|c|c|c|c|}
\hline Sample & Common name & $\begin{array}{c}\text { Source and } \\
\text { number of samples } \\
\text { from each type of } \\
\text { source }\end{array}$ & $\begin{array}{l}\text { Total viable count on } \\
\text { MRS agar }(\mathrm{CFU} / \mathrm{g})\end{array}$ & $\begin{array}{c}\text { Code of } \\
\text { representative } \\
\text { LAB isolates }\end{array}$ \\
\hline $\begin{array}{l}\text { Spondias } \\
\text { dulcis }\end{array}$ & $\begin{array}{l}\text { Ambarella/ } \\
\text { Kedondong }\end{array}$ & Stall $(n=5)$ & $<1.0 \times 10$ & No isolates \\
\hline $\begin{array}{l}\text { Spondias } \\
\text { dulcis }\end{array}$ & $\begin{array}{l}\text { Ambarella/ } \\
\text { Kedondong }\end{array}$ & Supermarket $(\mathrm{n}=3)$ & $1.0 \times 10^{4}$ & LABS1, LABS2 \\
\hline $\begin{array}{l}\text { Spondias } \\
\text { dulcis }\end{array}$ & $\begin{array}{l}\text { Ambarella/ } \\
\text { Kedondong }\end{array}$ & Wet market $(n=3)$ & $<1.0 \times 10$ & No isolates \\
\hline
\end{tabular}

Two LAB isolates (coded as LABS1 and LABS2) that survived the sub-culturing process and met the characteristic of LAB on MRS agar were selected for identification based on their morphology on MRS agar and biochemical testing. The LAB isolates were usually round shape and white in color on MRS agar and the same condition was observed for LABS1 and LABS2 (Table 2 and Figure 2). The LABS1 was a Gram-positive bacteria in rod/bacilli form as observed during Gram staining while LABS2 was coccus/round shape. Both isolates were treated with $3 \%$ hydrogen peroxide and were catalase negative. Both the Gram staining and catalase reaction are the most common morphological and biochemical test used for identification of LAB. The Gram staining is to identify bacteria based on cell wall characteristics and LAB are Gram-positive bacteria which have a peptidoglycan rich cell wall. The LAB are also generally known as catalase negative where they produce small amount of catalase enzyme thus are not able to break hydrogen peroxide into water and oxygen and can be seen as not producing bubbles in the catalase reaction test [21]. The isolates were then subjected for phenotypic identification using molecular method and were identified as Lactobacillus fermentum (LABS1) and Enterococcus durans (LABS2) from BLAST results as shown in Table 2.

Table 2 Morphological, biochemical and molecular identification of lactic acid bacteria (LAB) isolates from Spondias dulcis (ambarella or kedondong).

\begin{tabular}{lcc}
\hline \multicolumn{1}{c}{ Identification method } & \multicolumn{2}{c}{ LAB code } \\
\cline { 2 - 3 } & LABS1 & LABS2 \\
\hline Morphological identification & Circle, white color & Circle, white color \\
Colony morphology on MRS agar & Rod & Round \\
Cell shape under microscope & & \\
\hline
\end{tabular}




\begin{tabular}{lcc}
\hline \multicolumn{1}{c}{ Identification method } & LABS1 & LABS2 \\
\cline { 2 - 3 } & & \\
\hline Biochemical identification & Gram-positive & Gram-positive \\
Gram staining reaction & Catalase negative & Catalase negative \\
Catalase activity & & Enterococcus \\
\hline Molecular identification by sequencing of 16S rRNA gene & duran \\
Best match in BLAST analysis & fermentum & NR_044704.2 \\
Accession number of the best match in BLAST analysis & NR_116238.1 & $98 \%$ \\
Identity score (\% similarity) & $97 \%$ & $97 \%$ \\
\hline
\end{tabular}

Antibacterial activity of isolated and identified LAB cell culture using agar spot test method

The agar spot test usually is the preliminary analysis done for determining the antibacterial activity of LAB [22]. It used the LAB cell cultures that were grown on MRS agar as a single spot and after incubation at $37 \pm 2{ }^{\circ} \mathrm{C}$ for $24 \mathrm{~h}$, the pathogenic bacteria to be tested against the LAB were poured onto the LAB spot. The LAB isolates that were able to inhibit any strains of bacterial pathogen and created an inhibition zone around the $\mathrm{LAB}$ spot were able to prove on their early potential of having the antibacterial property [23]. In this study, both LABS1 and LABS2 isolates were tested on their ability to inhibit 10 bacterial pathogens. Table 3 summarizes the findings and shows that both isolates were able to inhibit all 5 Gram-positive bacterial pathogens which were B. cereus, E. faecalis, L. innocua, L. monocytogenes and $S$. aureus and also all 5 Gram-negative bacterial pathogens which were $C$. muytjensii E. coli, $S$. Poona, $S$. Typhimurium and $V$. parahaemolyticus. The results also indicated that the sizes of inhibition zones were varied depending on both LAB and pathogenic strains. Ahmad et al. [24] reported that the LAB, which were 3 strains of Lactobacillus plantarum from their study were able to inhibit the growth of pathogenic $E$. coli and $S$. aureus. They also concluded that the inhibition zones were also varied depending on both LAB and pathogenic strains.

Table 3 Antibacterial activity of isolated lactic acid bacteria (LAB) cells from Spondias dulcis (ambarella or kedondong) against Gram-positive and Gram-negative bacterial pathogens by agar spot test method.

\begin{tabular}{cccccc}
\hline LAB code & \multicolumn{5}{c}{ Diameter of inhibition zone (mm) } \\
\hline & BC & EF & LI & LM & SA \\
LABS1 & $(+)$ & $(++)$ & $(+++)$ & $(+++)$ & $(+++)$ \\
LABS2 & $(+)$ & $(++)$ & $(+++)$ & $(+++)$ & $(+++)$ \\
& CM & EC & SP & ST & VP \\
LABS1 & $(++)$ & $(++)$ & $(+++)$ & $(+++)$ & $(+++)$ \\
LABS2 & $(++)$ & $(++)$ & $(+++)$ & $(+++)$ & $(+++)$ \\
\hline
\end{tabular}

Note: The different scores reflect the different degree of growth inhibition zone expressed in $\mathrm{mm}$ as the mean of 3 replicates, as below:

$(+)$ zone of inhibition between 5 and $10 \mathrm{~mm}$

$(++)$ zone of inhibition between 11 and $17 \mathrm{~mm}$

$(+++)$ zone of inhibition $>17 \mathrm{~mm}$

Gram-positive bacterial pathogens: BC (Bacillus cereus $\mathrm{ATCC}^{\circledR} 10876^{\mathrm{TM}}$ ), EF (Enterococcus faecalis ATCC $^{\circledR} 19433^{\mathrm{TM}}$ ), LI (Listeria innocua ATCC $^{(\mathcal{B}} 33090^{\mathrm{TM}}$ ), LM (Listeria monocytogenes ATCC $^{\circledR} 7644^{\mathrm{TM}}$ ), SA (Staphylococcus aureus ATCC ${ }^{\circledR} 25923^{\mathrm{TM}}$ )

Gram-negative bacterial pathogens: CM (Cronobacter muytjensii $\mathrm{ATCC}^{\circledR} 51329^{\mathrm{TM}}$ ), EC (Escherichia coli ATCC $^{\circledR} 48888^{\mathrm{TM}}$ ), SP (Salmonella enterica serovar Poona NCTC 4840), ST (Salmonella enterica serovar Typhimurium ATCC ${ }^{\circledR} 14028^{\mathrm{TM}}$ ), VP (Vibrio parahaemolyticus NCTC 10885) 


\section{Antibacterial activity evaluation of CFS using agar well diffusion method}

The antibacterial activity of LAB can be due to the production of several antibacterial compound produced during their growth [23] and excreted extracellularly [25]. The LAB secreted various inhibitory compounds that are responsible for its antibacterial activity such as organic acids, hydrogen peroxide and bacteriocin [25]. Thus, the CFS of the LAB isolates that have shown inhibitory activity based on the preliminary evaluation using agar spot test were used to evaluate the antibacterial activity of their CFS using well diffusion method. The result showed that all untreated CFS of both LAB isolates have the antibacterial effect against selected pathogens and the sizes of the inhibition zones were varied as summarized in Table 4. On the other hand, the neutralized CFS of both isolates showed no inhibition zones against all tested bacterial pathogens. The same finding was also being reported by Hor and Liong [25]. Failure of the neutralized CFS to create inhibition zones indicated that the acidic condition of the CFS that was due to the presence of organic acid might have contributed to the antibacterial activity of the isolates.

Table 4 Antibacterial activity of cell free supernatant (CFS), neutralized CFS and enzyme (catalase and trypsin) treated CFS of lactic acid bacteria (LAB) isolates against Gram-positive and Gram-negative bacteria.

\begin{tabular}{|c|c|c|c|c|c|c|}
\hline \multirow{2}{*}{$\begin{array}{l}\text { LAB } \\
\text { code }\end{array}$} & \multirow{2}{*}{ Type of CFS } & \multicolumn{5}{|c|}{ Inhibition zone (mm) } \\
\hline & & BC & EF & LI & LM & $\mathbf{S A}$ \\
\hline \multirow[t]{4}{*}{ LABS1 } & Untreated & $9.00 \pm 0.00^{\mathrm{a}}$ & $9.00 \pm 0.00^{\mathrm{a}}$ & $9.00 \pm 0.00^{\mathrm{a}}$ & $10.33 \pm 0.58^{\mathrm{a}}$ & $11.33 \pm 0.58^{\mathrm{a}}$ \\
\hline & Neutralized & $0.00 \pm 0.00^{\mathrm{b}}$ & $0.00 \pm 0.00^{\mathrm{b}}$ & $0.00 \pm 0.00^{\mathrm{b}}$ & $0.00 \pm 0.00^{\mathrm{b}}$ & $0.00 \pm 0.00^{\mathrm{b}}$ \\
\hline & Catalase & $10.00 \pm 0.00^{\mathrm{a}}$ & $9.67 \pm 0.00^{\mathrm{a}}$ & $10.33 \pm 0.58^{\mathrm{a}}$ & $10.67 \pm 0.58^{\mathrm{a}}$ & $11.67 \pm 1.53^{\mathrm{a}}$ \\
\hline & Trypsin & $8.67 \pm 0.58^{\mathrm{a}}$ & $9.33 \pm 0.58^{\mathrm{a}}$ & $9.00 \pm 0.00^{\mathrm{a}}$ & $9.67 \pm 0.00^{\mathrm{a}}$ & $12.00 \pm 1.73^{\mathrm{a}}$ \\
\hline \multirow[t]{5}{*}{ LABS2 } & Untreated & $9.33 \pm 0.58^{\mathrm{a}}$ & $9.33 \pm 0.58^{\mathrm{a}}$ & $9.00 \pm 0.00^{\mathrm{a}}$ & $10.67 \pm 0.58^{\mathrm{a}}$ & $9.67 \pm 0.58^{\mathrm{a}}$ \\
\hline & Neutralized & $0.00 \pm 0.00^{\mathrm{b}}$ & $0.00 \pm 0.00^{\mathrm{b}}$ & $0.00 \pm 0.00^{\mathrm{b}}$ & $0.00 \pm 0.00^{\mathrm{b}}$ & $0.00 \pm 0.00^{\mathrm{b}}$ \\
\hline & Catalase & $9.00 \pm 0.00^{\mathrm{a}}$ & $9.00 \pm 0.00^{\mathrm{a}}$ & $9.00 \pm 0.00^{\mathrm{a}}$ & $9.00 \pm 0.00^{\mathrm{a}}$ & $9.00 \pm 0.00^{\mathrm{a}}$ \\
\hline & Trypsin & $10.00 \pm 0.00^{\mathrm{a}}$ & $10.00 \pm 0.00^{\mathrm{a}}$ & $10.33 \pm 0.58^{\mathrm{a}}$ & $9.67 \pm 0.00^{\mathrm{a}}$ & $9.33 \pm 0.58^{\mathrm{a}}$ \\
\hline & & CM & $\mathrm{EC}$ & SP & ST & VP \\
\hline \multirow[t]{4}{*}{ LABS1 } & Untreated & $10.33 \pm 0.58^{\mathrm{a}}$ & $11.33 \pm 1.15^{\mathrm{a}}$ & $9.67 \pm 0.58^{\mathrm{a}}$ & $11.67 \pm 2.89^{\mathrm{a}}$ & $10.67 \pm 1.15^{\mathrm{a}}$ \\
\hline & Neutralized & $0.00 \pm 0.00^{\mathrm{b}}$ & $0.00 \pm 0.00^{\mathrm{b}}$ & $0.00 \pm 0.00^{\mathrm{b}}$ & $0.00 \pm 0.00^{\mathrm{b}}$ & $0.00 \pm 0.00^{\mathrm{b}}$ \\
\hline & Catalase & $10.00 \pm 0.00^{\mathrm{a}}$ & $11.00 \pm 1.00^{\mathrm{a}}$ & $9.00 \pm 0.00^{\mathrm{a}}$ & $11.00 \pm 1.00^{\mathrm{a}}$ & $10.00 \pm 0.00^{\mathrm{a}}$ \\
\hline & Trypsin & $10.00 \pm 0.00^{\mathrm{a}}$ & $11.00 \pm 0.00^{\mathrm{a}}$ & $9.00 \pm 0.00^{\mathrm{a}}$ & $10.00 \pm 1.00^{\mathrm{a}}$ & $11.00 \pm 0.00^{\mathrm{a}}$ \\
\hline \multirow[t]{4}{*}{ LABS2 } & Untreated & $10.00 \pm 0.00^{\mathrm{a}}$ & $12.33 \pm 0.58^{\mathrm{a}}$ & $10.00 \pm 1.00^{\mathrm{a}}$ & $10.33 \pm 0.58^{\mathrm{a}}$ & $10.33 \pm 0.58^{\mathrm{a}}$ \\
\hline & Neutralized & $0.00 \pm 0.00^{\mathrm{b}}$ & $0.00 \pm 0.00^{\mathrm{b}}$ & $0.00 \pm 0.00^{\mathrm{b}}$ & $0.00 \pm 0.00^{\mathrm{b}}$ & $0.00 \pm 0.00^{\mathrm{b}}$ \\
\hline & Catalase & $9.67 \pm 0.58^{\mathrm{a}}$ & $13.00 \pm 1.00^{\mathrm{a}}$ & $10.00 \pm 0.00^{\mathrm{a}}$ & $9.67 \pm 0.58^{\mathrm{a}}$ & $10.00 \pm 0.00^{\mathrm{a}}$ \\
\hline & Trypsin & $9.00 \pm 0.00^{\mathrm{a}}$ & $12.00 \pm 0.00^{\mathrm{a}}$ & $10.00 \pm 0.00^{\mathrm{a}}$ & $10.00 \pm 0.00^{\mathrm{a}}$ & $11.00 \pm 0.00^{\mathrm{a}}$ \\
\hline
\end{tabular}

Note: CFS: Cell free supernatant

The results are the growth inhibition zone expressed in $\mathrm{mm}$ as the mean of 3 replicates, \pm standard deviations.

${ }^{\mathrm{a}-\mathrm{b}}$ Different superscripted lowercase letters indicate that the growth inhibition zones in the same column, within the same LAB code and same pathogen strain are significantly different.

Gram-positive bacterial pathogens: BC (Bacillus cereus ATCC ${ }^{\circledR} 10876^{\mathrm{TM}}$ ), EF (Enterococcus faecalis ATCC $^{\circledR} 19433^{\mathrm{TM}}$ ), LI (Listeria innocua ATCC $^{\circledR} 33090^{\mathrm{TM}}$ ), LM (Listeria monocytogenes ATCC $^{\circledR} 7644^{\mathrm{TM}}$ ), SA (Staphylococcus aureus ATCC ${ }^{\circledR} 25923^{\mathrm{TM}}$ )

Gram-negative bacterial pathogens: CM (Cronobacter muytjensii $\mathrm{ATCC}^{\circledR} 51329^{\mathrm{TM}}$ ), EC (Escherichia coli ATCC $^{\circledR} 48888^{\mathrm{TM}}$ ), SP (Salmonella enterica serovar Poona NCTC 4840), ST (Salmonella enterica serovar Typhimurium ATCC $^{\circledR} 14028^{\mathrm{TM}}$ ), VP (Vibrio parahaemolyticus NCTC 10885)

Enzyme treatment using catalase and trypsin have no significant effect to the antibacterial activity of all LAB isolates against all pathogens if compared to untreated CFS. Summary of the results are as shown in Table 4. The catalase treatment was performed to rule out the antibacterial activity by hydrogen peroxide from CFS. The catalase enzyme will break hydrogen peroxide compound into water and oxygen therefore reduce the hydrogen peroxide amount in the CFS [26]. The ability of catalase treated CFS with 
reduced amount of hydrogen peroxide to maintain their inhibitory effect against pathogen has confirmed that hydrogen peroxide might not contribute to the antibacterial activity of the strains. Other than organic acids and hydrogen peroxide, proteinaceous compounds such as bacteriocin might possibly be present or present in a very low amount in the CFS as antibacterial compound. Proteolytic enzymes including trypsin will inactivate the proteinaceous compound when added to the CFS [27]. The ability of the trypsin treated CFS in this study to maintain their inhibitory effect when compared to untreated CFS showed that the proteinaceous compound might not be responsible for the antimicrobial activity of the CFS of the LAB from $S$. dulcis.

\section{Conclusions}

Two isolates of LAB identified as Lactobacillus fermentum (LABS1) and Enterococcus durans (LABS2) isolated from pickled Spondias dulcis (ambarella) possessed antibacterial activity against a total of 10 Gram-positive and Gram-negative foodborne pathogens. The antibacterial activity performed using CFS of both LABS1 and LABS2 also suggested that they may have potential as natural preservative in the future. However, more study needs to be done to confirm on their potential and application.

\section{Acknowledgements}

The authors would like to acknowledge that this work forms part of a research project funded by the Ministry of Education (FRGS/1/2017/WAB01/UKM/02/4) and the Universiti Kebangsaan Malaysia (GPK007337).

\section{References}

[1] R Zhong, X Xu and L Wang. Food supply chain management: Systems, implementations, and future research. Ind. Manag. Data Syst. 2017; 117, 2085-114.

[2] X Lu, L Yi, J Dang, Y Dang and B Liu. Purification of novel bacteriocin produced by Lactobacillus coryniformis MXJ 32 for inhibiting bacterial foodborne pathogens including antibiotic-resistant microorganisms. Food Contr. 2014; 46, 264-71.

[3] MCS Campelo, JMS Medeiros and JBA Silva. Natural products in food preservation. Int. Food Res. J. 2019; 26, 41-6.

[4] Z Sharif, F Mustapha, J Jai, NM Yusof and N Zaki. Review on methods for preservation and natural preservatives for extending the food longevity. Chem. Eng. Res. Bull. 2017; 19, 145-53.

[5] TV Plavec and A Berlec. Safety aspects of genetically modified lactic acid bacteria. Microorganisms 2020; 8, 297.

[6] DM Soltan, M Zamaniahari, A Davoodabadi, M Hosseini and Z Rajabi. Identification and characterization of probiotic lactic acid bacteria isolated from traditional Persian pickled vegetables. GMS Hyg. Infect. Contr. 2017; 12, 1-7.

[7] M Mohammed, SH Ahmad, RA Bakar and TL Abdullah. Golden apple (Spondias dulcis Forst. syn. Spondias Cytherea Sonn.). In: MY Elhadi (Ed.). Postharvest biology and technology of tropical and subtropical fruits. Woodhead Publishing, Oxford, 2011, p. 159-78.

[8] AR Sukirah, AK Ainaa, M Azlina, LM Dang, H Aminuddin, AS Shaiful, GH Tan, YAR Nur, AO Muhammad and L Kamariah. Identification of potential indigenous microbe from local fermented vegetables with antimicrobial activity. Sci. Herit. J. 2017; 1, 1-3.

[9] A Roy and C Rai. Isolation and characterization of lactic acid bacteria with probiotic potential from pickles. Biosci. Discov. 2017; 8, 866-75.

[10] A Wallace and T Hammack. Food sampling and preparation of sample homogenate. In: RI Merker (Ed.). Bacteriological analytical manual (BAM). AOAC International, Maryland, 1998, p. 1-19.

[11] WY Kam, WM Wan Aida, AM Sahilah and MY Maskat. Volatile compounds and lactic acid bacteria in spontaneous fermented sourdough. Sains Malaysiana 2011; 40, 135-8.

[12] S Nanasombat, S Phunpruch and T Jaichalad. Screening and identification of lactic acid bacteria from raw seafoods and Thai fermented seafood products for their potential use as starter cultures. Songklanakarin J. Sci. Tech. 2012; 34, 255-62.

[13] H Nurul Huda and AS Norrakiah. Isolation of lactic acid bacteria with potential protective culture characteristics from fruits. AIP Conf. Proc. 2015; 1678, 050042.

[14] WC Tan, SJ Lim and WA Wan Mustapha. Pencirian bakteria asid laktik dan sebatian aroma ikan pekasam. Sains Malaysiana 2017; 46, 439-48. 
[15] M Nur Ilida, AM Musaalbakri and AS Norrakiah. Antibacterial potential of lactic acid bacteria isolated from local pickled Eleiodoxa conferta (kelubi) against selected foodborne pathogens. Malays. J. Microbiol. 2018; 14, 490-6.

[16] MP Arena, A Silvain, G Normanno, F Grieco, D Drider, G Spano and D Fiocco. Use of Lactobacillus plantarum strains as a bio-control strategy against foodborne pathogenic microorganisms. Front. Microbiol. 2016; 7, 464.

[17] SR Vahedi, KR Kasra and P Ghadam. The inhibitory effect of bacteriocin produced by Lactobacillus acidophilus ATCC 4356 and Lactobacillus plantarum ATCC 8014 on planktonic cells and biofilms of Serratia marcescens. Turk. J. Med. Sci. 2016; 46, 1188-96.

[18] S Ozcelik, E Kuley and F Ozogul. Formation of lactic, acetic, succinic, propionic, formic and butyric acid by lactic acid bacteria. LWT Food Sci. Tech. 2016; 73, 536-42.

[19] V Sumathi and D Reetha. Screening of lactic acid bacteria for their antimicrobial activity against pathogenic bacteria. Int. J. Pharmaceut. Biol. Arch. 2012; 3, 802-8.

[20] E Yang, L Fan, Y Jiang, C Doucette and S Filmore. Antimicrobial activity of bacteriocin-producing lactic acid bacteria isolated from cheeses and yogurts. AMB Express 2012; 2, 48.

[21] MP Astuti. Isolation, characterization and identification lactic acid bacteria from chicken waste faeces that potential as probiotics. Int. J. Sci. Res. Publ. 2016; 6, 180-91.

[22] SS Tejero, J Barlow, A Costabile, GR Gibson and I Rowland. In vitro evaluation of the antimicrobial activity of a range of probiotics against pathogens: Evidence for the effects of organic acids. Anaerobe 2012; 18, 530-8.

[23] TQ Ha and TMT Hoa. Selection of lactic acid bacteria producing bacteriocin. J. Viet. Environ. $2016 ; 8,271-6$.

[24] A Ahmad, WB Yap, NT Kofli and AR Ghazali. Probiotic potentials of Lactobacillus plantarum isolated from fermented durian (Tempoyak), a Malaysian traditional condiment. Food Sci. Nutr. $2018 ; 6,1370-7$.

[25] YY Hor and MT Liong. Use of extracellular extracts of lactic acid bacteria and bifidobacteria for the inhibition of dermatological pathogen Staphylococcus aureus. Dermatol. Sin. 2014; 32, 141-7.

[26] WKA Da Costa, GT De Souza, LR Brandao, RC De Lima, EF Garcia, MDS Lima, EL De Souza, M Saarela and M Magnani. Exploiting antagonistic activity of fruit-derived Lactobacillus to control pathogenic bacteria in fresh cheese and chicken meat. Food Res. Int. 2018; 108, 172-82.

[27] TH Lin and TM Pan. Characterization of an antimicrobial substance produced by Lactobacillus plantarum NTU 102. J. Microbiol. Immunol. Infect. 2019; 52, 409-17. 